\title{
Ash regeneration capacity after emerald ash borer (EAB) outbreaks: Some early results
}

\author{
by I. Aubin ${ }^{1}$, F. Cardou 1 , K. Ryall ${ }^{1}$, D. Kreutzweiser ${ }^{1}$ and T. Scarr²
}

\begin{abstract}
The emerald ash borer (EAB), a wood-boring beetle native of Asia, has killed millions of ash trees in North America since its detection in 2002. The rapid spread of the infestation and the widespread distribution and importance of ash in North America, coupled with the genus' high vulnerability raise the crucial question of ash regeneration capacity following EAB infestation and its potentially broad ecological implications. We report on ash regeneration and infestation at the epicentre of the initial EAB invasion in Canada (near Windsor, Ontario). Up to 12 years after detection of the outbreak, we found abundant ash regeneration in the impacted area. However, the likelihood of these stems reaching maturity appears low. Dissection of a subsample of saplings allowed us to confirm the presence of an active residual EAB population, with infestation in 19\% of regenerating stems (including stems as small as $2 \mathrm{~cm}$ in basal diameter). A vigorous regenerating ash cohort comprising a large portion of stump resprouts might allow for survival of the genus in the landscape for decades, but it is likely that the key functional role played by ash species will be definitively altered as a result of persistent EABcaused mortality in maturing trees.
\end{abstract}

Keywords: Agrilus planipennis, Fraxinus species, invasive forest pest, post-outbreak ash establishment, ash infestation.

\section{RÉSUMÉ}

Lagrile du frêne (EAB), un coléoptère indigène de l'Asie, a tué des millions de frênes en Amérique du Nord depuis sa détection en 2002. La propagation rapide de l'infestation, l'importance du frêne en Amérique du Nord, combinées à sa grande vulnérabilité, soulèvent la question de la capacité de régénération du frêne et des implications écologiques d’une telle infestation. Nous présentons ici des résultats portant sur la régénération du frêne et de son niveau d'infestation à lépicentre de l'invasion au Canada (près de Windsor, en Ontario). Jusquà 12 ans après la détection de lépidémie, nous avons trouvé une régénération abondante de frênes dans la zone touchée. Cependant, la probabilité que ces tiges atteignent la maturité semble faible. La dissection d'un sous-échantillon de gaules nous a permis de confirmer la présence d'une population résiduelle active d’agrile du frêne, avec une infestation chez $19 \%$ des tiges (y compris des tiges aussi petites que $2 \mathrm{~cm}$ de diamètre basal). Une vigoureuse régénération comprenant une grande partie de rejets de souches pourrait permettre la survie des frênes dans le paysage pendant plusieurs décennies, mais il est probable que le rôle fonctionnel clé joué par les frênes sera définitivement modifié en raison de la persistance de l'agrile causant la mortalité de la régénération au fur et à mesure de sa maturation.

Mots-clés: Agrilus planipennis, Fraxinus, ravageurs forestiers, établissement du frêne après l'épidémie, infestation du frêne

\section{Introduction}

The emerald ash borer (EAB), Agrilus planipennis Fairmaire (Coleoptera: Buprestidae), a wood-boring beetle native to northeastern China, Korea and eastern Russia (Jendek 1994), was first discovered in North America in 2002 in Detroit, Michigan, USA and in Windsor, Ontario, Canada (Haack et al. 2002). In the time since, infestations have spread to 24 US States and two Canadian provinces (USDA and MSU 2004; Fig. 1) through wave-like spread over short distances and unpredictable long-distance dispersal events, usually attributed to human transport of infested firewood and nursery stock (Cappaert et al. 2005, Siegert et al. 2010).

Emerald ash borer has caused extensive mortality in every North American ash species it has encountered, with reported mortality rising to $99 \%$ in black and green ash populations (Fraxinus nigra Marsh., F. pennsylvanica Marsh.) and to a lesser extent in white ash (F. Americana L.) (Anulewicz et al. 2007,
Tanis and McCullough 2012, Klooster et al. 2014). Aerial surveys in Ontario have mapped 196390 ha of tree decline and mortality caused by EAB since 2004 (OMNRF 2015). In contrast with its behaviour in its native range (Wei et al. 2004), in North America EAB attacks healthy trees and is able to infest and kill ash trees of all sizes, from saplings $(>2.5 \mathrm{~cm} \mathrm{DBH})$ to mature trees (Herms and McCullough 2014). Larvae of EAB feed on the phloem layer under the bark, disrupting the flow of water and nutrients and ultimately girdling and killing the affected tree. In larger trees, infestation typically begins up in the crown, with galleries being established in the main stem after one to several years of infestation (Haack et al. 2002, Ryall et al. 2011). Tree mortality typically occurs within about six years, with extensive stand-level mortality two to three years after the initial detection of the infestation (Knight et al. 2013).

In Canada, ash species distribution stretches from the Maritimes to Saskatchewan, and as far north as Anticosti

\footnotetext{
${ }^{1}$ Great Lakes Forestry Centre, Canadian Forest Service, Natural Resources Canada, 1219 Queen St. East, Sault Ste. Marie, Ontario, Canada, P6A 2E5 Corresponding author email: Isabelle.Aubin@NRCan-RNCan.gc.ca

${ }^{2}$ Ontario Ministry of Natural Resources and Forestry, 70 Foster Drive, Sault Ste. Marie, Ontario, Canada, P6A 6V5
} 


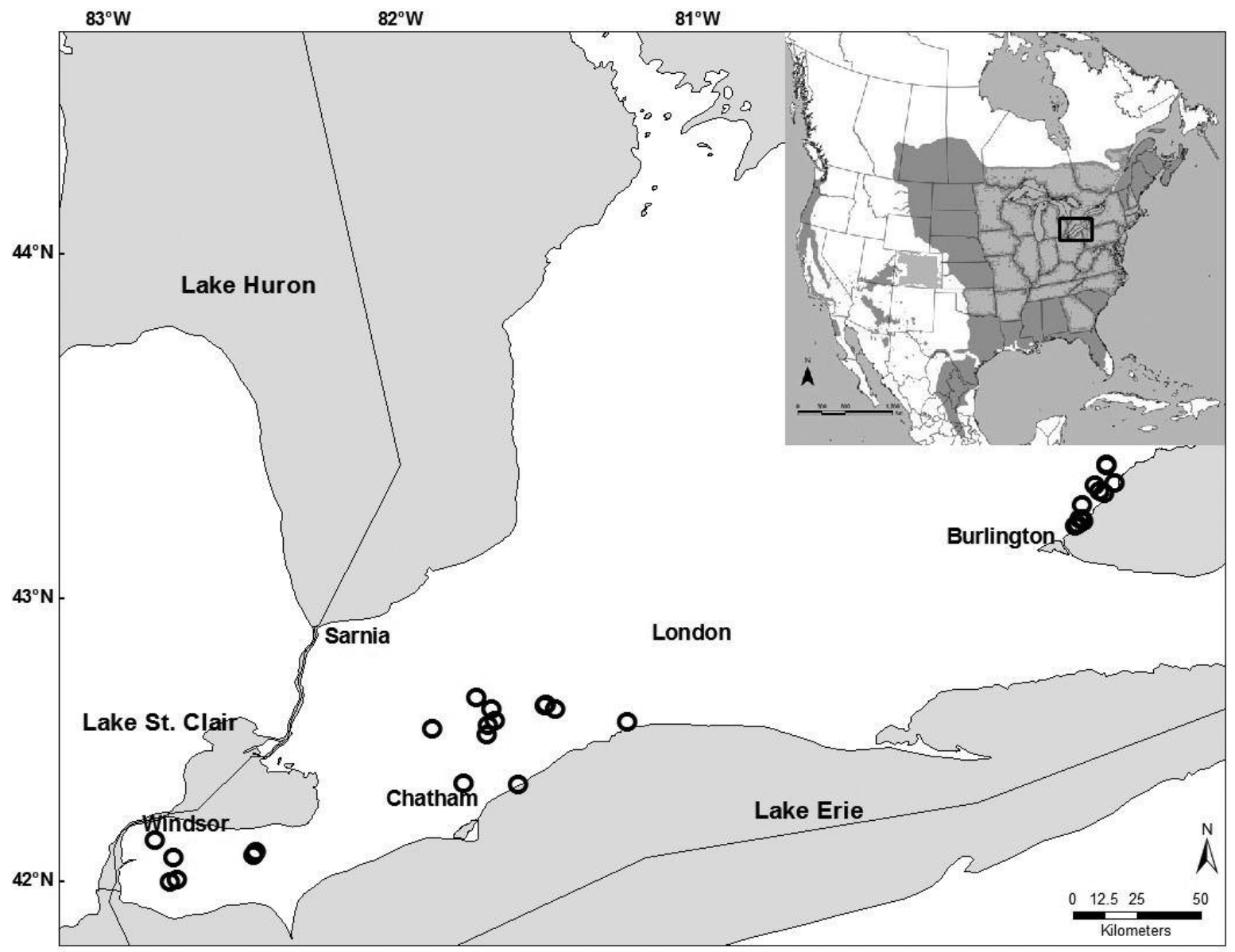

Fig. 1. Study site location. Approximate range distribution of ash species (dark grey area; digitized from E.L. Little, Jr. 1971) and infested states and provinces as of February 2015 (light grey area; USDA and MSU 2004) are presented in the left corner.

Island and Lake Winnipeg (Fig. 1). Of the six native species, only three have widespread geographic distributions: F. americana L. (white ash), F. pennsylvanica Marsh. (green ash, sometimes called red ash), and F. nigra Marsh (black ash). Effective seed producers and dispersers with frequent mast years, ash are successful colonizers in disturbed stands, particularly white ash which is often a component of successful afforestation of abandoned farmlands (e.g., D’Orangeville et al. 2008). Although rarely dominant, white ash occurs widely on dry-mesic and mesic uplands, and is officially listed as a component species for over 25 forest cover types (Wright 1959). Green ash typically forms groves in mesic to wet-mesic floodplains and riparian zones (Farrar 1995, MacFarlane and Meyer 2005). Because of its high tolerance for urban conditions, green ash has also been widely planted in cities (Macfarlane and Meyer 2005). Black ash is found in poorly drained sites and has the most extensive range among all ash species in Canada (Farrar 1995). Across forest types, ash species emerge as foundation species; as such, their disappearance could destabilize associated biota, jeopardizing function and stability in both terrestrial and aquatic ecosystems (Ellison $e t$ al. 2005, Kominoski et al. 2007, Ghandi and Herms 2010).
With the advance of the EAB infestation in northeastern North America, it is becoming increasingly clear that North American ash species and the ecosystems they are part of will undergo substantial changes. A large part of $\mathrm{EAB}$ research has been primarily concerned with the immediate effects of the infestation and the means of slowing it. As we move from reactive research to post-invasion consequences for North American forests, one key question will be the fate of ash regeneration. Early studies in Michigan have documented successional dynamics shortly after the outbreak (Kashian and Witter 2011, Knight et al. 2011, Flower et al. 2013, Klooster et al. 2014); emerging patterns show initially high densities of ash seedlings and saplings and decreasing densities of new germinants, suggesting that the continued presence of ash in this landscape will likely hinge on the survival of the current orphaned cohort. Their persistence will depend on complex interactions between environmental factors and management activities, but also on ash life-history traits. Indeed, for other species that have faced exotic pests such as American chestnut, Castanea dentata (Marsh.) and American elm, Ulmus americana L., traits such as seed-bearing age and seed production, when combined to the characteristics of 
their respective exotic pests, have had significant impact on their persistence in the landscape. These characteristics, and particularly their interaction with the infestation dynamics of $\mathrm{EAB}$ in regenerating stems, remain key points to elucidate.

In this short note, we report on ash regeneration and infestation surveys conducted at the Canadian epicentre of EAB invasion, up to 12 years after the initial detection of the outbreak. Based on a limited number of sites, these are the first data on potential ash recovery in the southern Ontario agricultural landscape. We examine the likelihood of ash establishment and survival in EAB-affected areas based on these data and on ash life-history traits. We also report on the effectiveness of visual assessment of EAB infestation in saplings as a potential tool for managers to assess ash regeneration capacity following the outbreak.

\section{Methods}

The survey was carried out in two regions of southwestern Ontario, selected to represent forest composition before and after infestation by EAB (Fig. 1). The first region, located in the Essex county area $\left(42^{\circ} 10^{\prime} 8.4^{\prime \prime} \mathrm{N} ; 82^{\circ} 49^{\prime} 33.6^{\prime \prime} \mathrm{W}\right)$, was near the initial site of EAB detection confirmed in 2002 (although establishment likely occurred around 10 years before Cappaert et al. 2005) and is therefore the area with the longest period of EAB infestation in Canada (hereafter designated "impacted area"). The second region comprised Lambton county $\left(42^{\circ} 39^{\prime} 18^{\prime \prime} \mathrm{N} ; 81^{\circ} 40^{\prime} 28.8^{\prime \prime} \mathrm{W}\right)$ and the Oakville area $\left(43^{\circ} 31^{\prime} 33.6^{\prime \prime} \mathrm{N} ; 7^{\circ} 41^{\prime} 20.4^{\prime \prime} \mathrm{W}\right)$, both considered to be at the leading edge of the infestation at the time of sampling. The low infestation impact at the time allows us to use it as a reference state for the ash population in the area. Both regions (impacted and reference state) are located within the Carolinian forest zone, with agriculture and urban areas dominating the landscape (Canada Center for Mapping and Earth Observation, 2010). Mean annual temperatures range between 8.0 ${ }^{\circ} \mathrm{C}$ and $9.6{ }^{\circ} \mathrm{C}$ and precipitation between $811 \mathrm{~mm}$ and 974 $\mathrm{mm}$; the growing season lasts on average 231 days. White ash is found as companion species in upland woodlots while green ash is mainly found in small groves in riparian areas. Black ash and blue ash (F. quadrangulata Michx) are also occasionally found in the area.

\section{Stand selection and characterization}

A total of 30 sites were selected where ash was currently or previously an important canopy component (live and dead ash representing $>35 \%$ of total basal area, Table 1; see electronic supplementary material for site-specific information). In the reference state region, 12 riparian forests and 12 upland woodlots were selected, for a total of 24 sites in that region. Because of the smaller size of the impacted area, only six sites that were at once large enough, with sufficient ash density (alive or dead), with no other obvious recent disturbance and in close proximity to the epicenter of the outbreak could be found in the impacted area: four riparian forests and two woodlots. Sites were distributed between urban and agricultural matrices and of comparable patch size.

At each site, a circular plot of $20 \mathrm{~m}$ to $30 \mathrm{~m}$ in diameter, depending on the size and habitat type of the stand, was established in 2011 (approximately nine years after initial detection of the infestation, hereafter called "years post-detection") in a high ash density patch, regardless of ash mortality. All plots were located at least $20 \mathrm{~m}$ away from the stand edge. To assess forest structure, living and dead trees (including stumps) of all species were identified; basal area and stem density were measured for all stems with a diameter at breast height $(\mathrm{DBH}) \geq 5 \mathrm{~cm}$ and height $>130 \mathrm{~cm}$, summarized by species, and converted to a per hectare basis.

Live ash basal area and stem density were resurveyed in impacted plots in 2014 (12 years post-detection) in order to follow the progression of ash survival and recruitment. Seed production and external signs of EAB infestation were also recorded for all live ash. Tree strata data were summarized by region (impacted, reference) for visual comparison.

\section{Ash regeneration}

Ash regeneration was also surveyed at each site during the summer of 2011. Four 2 × 2 m quadrats were systematically located $5 \mathrm{~m}$ from the centre of the circular plot in each cardinal direction. In each quadrat, the number of established seedlings (between $50 \mathrm{~cm}$ and $130 \mathrm{~cm}$ in height) and saplings $(>130 \mathrm{~cm}$ in height and $<5 \mathrm{~cm}$ in $\mathrm{DBH}$ ) were recorded and converted into regeneration density on a per hectare basis. Ash regeneration was also assessed during the re-survey of

Table 1. Summary of tree strata characteristics for reference sites and impacted sites (measured 9 and 12 years post-detection of the infestation). Means are presented with standard error in parentheses (DBH: diameter at breast height).

\begin{tabular}{|c|c|c|c|c|c|c|c|}
\hline \multirow{4}{*}{ \# of sites } & \multirow{4}{*}{$\mathbf{n}$} & \multicolumn{2}{|c|}{ Reference state } & \multicolumn{4}{|c|}{ Impacted } \\
\hline & & & & \multicolumn{2}{|c|}{9 years post-detection } & \multicolumn{2}{|c|}{12 years post-detection } \\
\hline & & \multicolumn{2}{|c|}{24} & \multicolumn{2}{|c|}{6} & \multicolumn{2}{|c|}{6} \\
\hline & & Ash & Other & Ash & Other & Ash & Other \\
\hline Basal area $\left(\mathrm{m}^{2} \mathbf{h} \mathbf{a}^{-1}\right)$ & $\begin{array}{l}\text { live } \\
\text { dead }\end{array}$ & $\begin{array}{c}21.65(1.55) \\
1.73(0.15)\end{array}$ & $\begin{array}{l}9.00(1.16) \\
0.16(0.06)\end{array}$ & $\begin{array}{c}0.10(0.06) \\
23.35(3.68)\end{array}$ & $\begin{array}{l}8.95(1.64) \\
0.48(0.32)\end{array}$ & $\begin{array}{c}0.09(0.05) \\
-\end{array}$ & $\begin{array}{l}- \\
-\end{array}$ \\
\hline Density (stems ha' ${ }^{-1}$ ) & $\begin{array}{l}\text { live } \\
\text { dead }\end{array}$ & $\begin{array}{c}419(44) \\
59(8)\end{array}$ & $\begin{array}{c}486(51) \\
13(4)\end{array}$ & $\begin{array}{c}21(11) \\
467(91)\end{array}$ & $\begin{array}{c}525(146) \\
27(17)\end{array}$ & $\begin{array}{c}24(13) \\
-\end{array}$ & $\begin{array}{l}- \\
-\end{array}$ \\
\hline $\mathrm{DBH}(\mathrm{cm})$ & $\begin{array}{l}\text { live } \\
\text { dead }\end{array}$ & $\begin{array}{l}26.3(1.1) \\
16.4(1.1)\end{array}$ & $\begin{array}{c}12.3(0.7) \\
9.9(1.3)\end{array}$ & $\begin{array}{c}7.3(1.2) \\
24.7(1.4)\end{array}$ & $\begin{array}{l}15.0(2.4) \\
14.7(0.1)\end{array}$ & $\begin{array}{c}6.9(0.6) \\
-\end{array}$ & $\begin{array}{l}- \\
-\end{array}$ \\
\hline
\end{tabular}


impacted plots in 2014, although the survey area was extended to the entire plot due to low regeneration density. The number of seedlings ( $<50 \mathrm{~cm}$ in height) and germinants (seedlings with cotyledon) were also recorded. The origin of regenerating stems was recorded (re-sprout from stump or seed) and expressed as a proportion of all regenerating stems. Data were summarized by region (impacted, reference), and regenerative stage (sapling, established seedling) for visual comparison although no statistical analysis was performed due to low statistical power.

\section{Sapling infestation}

We assessed EAB infestation levels and the vigor of ash saplings 10 years after the initial detection of the infestation (summer 2012) by revisiting impacted sites which had exhibited substantial ash regeneration during our initial survey (five out of six sites). At each site, 30 live saplings with a basal diameter $>2 \mathrm{~cm}$ were systematically selected along a two metre-wide transect. For each stem, the overall vigour was assessed using a 1-4 scoring system (1: healthy with a good apical growth increment; 2: healthy with a limited growth; 3 : light to moderate decline; 4: severe decline). Basal diameter, height and regeneration type (from seed or sprout) were recorded. The specific ash species (where possible) and external signs of EAB infestation (bark cracks and other lesions such as woodpecker holes, EAB exit holes, epicormic shoots) were also noted. EAB infestation status (i.e., presence or absence) was ascertained for all stems via dissection. The stem was cut at the ground level and the bark peeled back in thin layers for at least $50 \mathrm{~cm}$ along the stem. The presence of $\mathrm{EAB}$ larvae or galleries was noted and any specimens were sent to the Great Lakes Forestry Centre laboratory to confirm identification.

To test whether infestation status could be detected from external signs or vigour, we applied a generalized linear mixed effects model with a binomial distribution. The two main effects (vigour and external signs) were tested using the glmer function of the lme 4 package (Bates et al. 2014). Signs that occurred only rarely were grouped by type of lesion; woodpecker holes and "other bark lesions" were grouped with "bark cracks" and treated as a presence/absence variable for analysis. To verify the effects of infestation and regeneration type on the vigour of ash saplings, we applied a generalized linear mixed effects model with a Poisson distribution. These two main effects (infestation; regeneration type) and the random effect "site" were tested using the glmmPQL function (Venables and Ripley 2002). All statistical analyses were carried out using the R statistical package (Statistical Package R 2009).

\section{Results and Discussion}

Nine years after the detection of the initial outbreak, ash was still an important component of the understory layer in our impacted area plots. We observed a vigorous regeneration response which is in line with the strong potential for colonization by seeds that is well-documented with this genus (USDA 2010). Impacted sites showed abundant ash regeneration, with an average density of above 5000 stem/ha for established seedlings and saplings (combined) compared to a little above 500 stem/ha in our reference sites (Fig. 2b). Similarly, in southeastern Michigan, Kashian and Witter (2011) observed abundant ash regeneration five years after the initial detection of the infestation, with mean densities of up to 3672 stems/ha for established seedlings and saplings in mesic hardwood stands. Significant decreases in new seedlings over time have also been reported for this region (Kashian and Witter 2011, Klooster et al 2014) and Burr and McCullough (2014) reported that they could not find any new germinants in postinfestation sites in 2010 or 2011 (southeastern Michigan). Ash seeds persist only two to three years in the seed bank (although for black ash some viable seeds have reportedly been found up to eight years; USDA and NRCS 2009) and the rapid depletion of the local seed bank following canopy mortality (Klooster et al. 2014) is likely to severely affect the recovery capacity of ash populations by seedling establishment. Although we could still find seedlings under $50 \mathrm{~cm}$ in height (393 stem/ha) in our resurvey of impacted sites 12 years post-detection, we recorded no new germinants and a marked, though highly variable, decline in established seedlings and saplings (Fig. 2b).

With the high dispersal ability and good germination rates of ash, we can expect that populations decimated by EAB may be able to recover from only a few surviving individuals. However, we could not find any survivors in the six sites we surveyed in the impacted area. No living mature ash $(>15 \mathrm{~cm}$ $\mathrm{DBH}$ ) were found among 15 other riparian areas surveyed as part of a parallel study in the same region, although 721 standing or fallen ash trees were counted (D.P. Kreutzweiser and S.S. Capell, pers. com., December 2014). The live individuals recorded in our six study sites ranged between $5 \mathrm{~cm}$ and $10.3 \mathrm{~cm} \mathrm{DBH}$ and were post-infestation regeneration (Fig. 2a). In contrast, in a survey specifically targeted at "lingering ash" remaining after the EAB invasion wave, Knight et al. (2012) observed 299 live ash trees with a DBH $\geq 10 \mathrm{~cm}$ at a site in northern Ohio, approximately $2.5 \%$ of the original population. They reported an average $\mathrm{DBH}$ of $17 \mathrm{~cm}$ for these lingering ash trees which suggests that at least some may represent vigorous post-infestation regeneration. Similarly, Burr and McCullough (2014) reported green ash survival rates ranging from $15 \%$ to $32 \%$ (depending on $\mathrm{DBH}$ ) in post-infestation sites. The difference in ash survival among the studies may indicate variations in ash innate resistance to $\mathrm{EAB}$ between populations, species or with site conditions. As broader areas become infested by $\mathrm{EAB}$, more comparative cross-regional and population studies will provide valuable insight on this subject.

In the absence of a few isolated survivors capable of acting as seed sources, ash population persistence in the landscape will depend on the orphaned cohort of ash regeneration: individuals that were either too small to attract the beetle at the time of the infestation, or that have since emerged as seedlings and re-sprouts from stumps. Whether or not this cohort will attain sexual maturity is highly dependent on post-infestation EAB dynamics. In impacted areas, EAB populations have predictably collapsed following the invasion wave due to the drastic reduction in carrying capacity following the extensive ash mortality. Ash and EAB can reasonably be expected to eventually reach equilibrium, where any increase in abundance will incur a corresponding increase in EAB abundance, the death of the new trees, and the return of EAB to low levels. Thus, ash persistence will hinge upon the ability of ash to regenerate under these circumstances, and the 

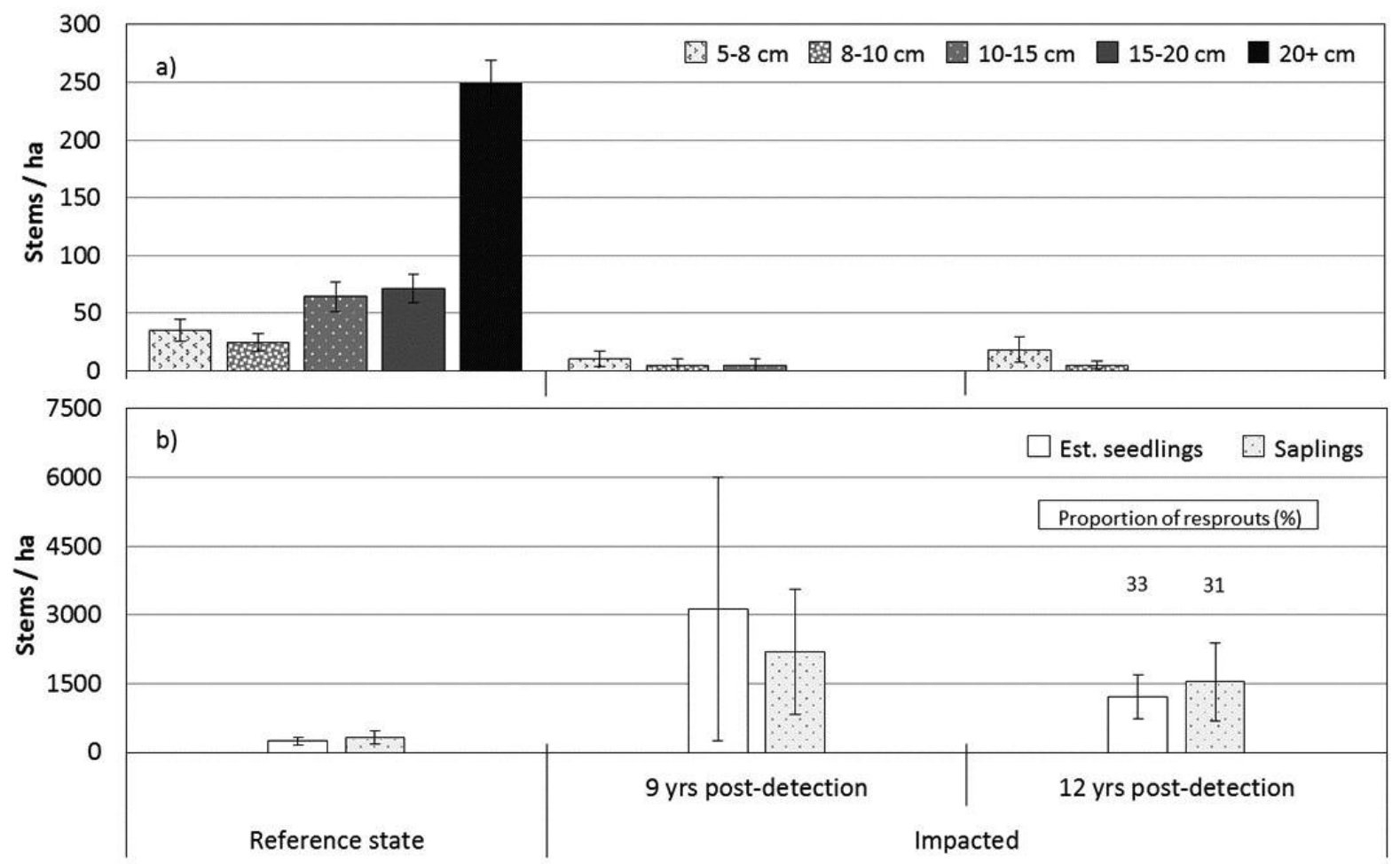

Fig. 2. Live ash diameter-density distribution ( \pm SEM stems/ha) for (a) trees ( $\mathrm{DBH}>5 \mathrm{~cm}$ ) and (b) regeneration (DBH $<5 \mathrm{~cm}$ ) at reference sites and at impacted sites, measured 9 years and 12 years post-detection of the infestation. Proportion of regeneration that are resprouts is given for impacted sites 12 years post-detection.

ability of EAB to find and successfully attack the new stems. Our results indicate that, years after mature ash mortality, active beetle populations remain in impacted areas. In our survey, the percentage of live saplings that were infested ranged from $7 \%$ to $43 \%$ among impacted sites, with the overall mean of $19 \%$ of regenerating stems. EAB infestation was detected in sapling stems as small as $2 \mathrm{~cm}$ in basal diameter (Fig. 3). The large proportion of infestation in larger basal diameters is in accordance with Timms et al. (2006), who observed higher gallery densities in infested stem sections above $7 \mathrm{~cm}$ in diameter. Although other surveys have documented regenerating stem mortality in parallel with trapbased EAB quantification (e.g., Klooster et al. 2014), to our knowledge no other systematic survey of regenerating ash have been conducted to assess the recolonization rates by remnant $\mathrm{EAB}$ populations in natural stand conditions.

These results confirm that the orphaned cohort of ash regeneration will be exposed to continued $\mathrm{EAB}$ pressure as they grow, and raise the question of whether these saplings will be able to produce seeds before being weakened or killed by infestation. Although they can occupy considerably different niches in the landscape, white and green ash are quite similar with respect to the life history traits that will determine their ability to persist under continued $\mathrm{EAB}$ presence. With both species, the first flowers may be produced by individuals as small as $8 \mathrm{~cm}$ in $\mathrm{DBH}$, although trees are larger (typically $20 \mathrm{~cm}-25 \mathrm{~cm} \mathrm{DBH}$ for white ash) before they flower abundantly (Burns and Honkala 1990). For dioecious species like green and white ash, reproduction success at low stem densities can be further delayed by the need for individuals of both sexes to mature within a few hundred metres of each other. Throughout the six impacted sites, very few saplings with a $\mathrm{DBH} \geq 8 \mathrm{~cm}$ were found and our results indicate a high degree of infestation amongst these (Fig. 3). With $\mathrm{EAB}$ capable of killing a healthy tree in two to four years, and small trees in a single year (Poland and McCullough 2006), it is unlikely that these saplings will reach maturity and produce viable seeds. In this context, young ash trees in open areas which typically attain sexual maturity more rapidly than in forest stands may play an important role for population persistence. For example, during the 2014 survey, two trees $(8 \mathrm{~cm}$ in $\mathrm{DBH}$ ) bearing seeds were found on the roadside in the vicinity of one of our impacted study sites, although none of the young ash we inventoried in our impacted plots were bearing seeds; both individuals had external signs of EAB infestation (i.e., bark cracks and $\mathrm{EAB}$ exit holes).

The question of the long-term persistence and abundance of ash in the landscape can be compared with that of the American elm and the American chestnut. In the case of the former, Dutch elm disease (Ophiostoma ulmi (Buism.) Nannf. and O. novo-ulmi Brasier) only affects adult trees and can take up to 15 years to kill an individual (Spooner and Roberts 


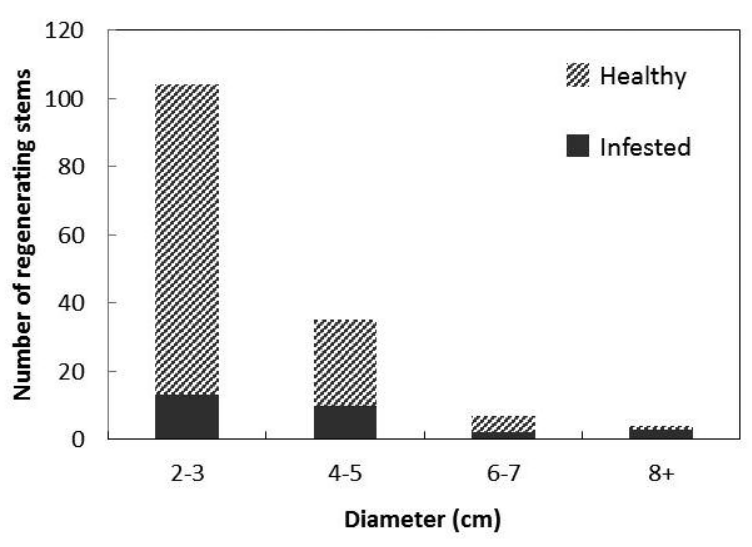

Fig. 3. Proportion of regenerating stems per basal diameter class 10 years post-detection of the infestation. Proportion of infested stems is also indicated; overall, $18.6 \%$ of regenerating stem are infested.

2010), enabling elm to reach sexual maturity (around 15-20 years) and bear seeds before ultimately dying. As a result, seventy-five years after the introduction of its exotic pathogen, American elm manages to persevere in eastern Canadian forests through successions of early-maturing and short-lifespan individuals, and through scattered large trees that either are escapees or have some level of resistance to the pathogen. Because the chestnut blight can kill an individual American chestnut tree before it reaches sexual maturity, they, on the other hand, have persisted in North American forests only due to their high re-sprouting ability, and with few exceptions, are now only found as low shrubs. In contrast with these examples, the time window within which EAB can kill is much shorter than the time necessary for an individual ash tree to reach seed-bearing age, a characteristic which may ultimately define the fate of North American ash species. Despite some similarity in reproductive strategy with American elm, it is therefore doubtful that ash will persist in the landscape in the same way.

Like American chestnut however, ash species have good re-sprouting ability (Burns and Honkala 1990, Dietze and Clark 2008). In Europe, ash (particularly F. excelsior L.) were among the most commonly coppiced trees (Jansen and Kuiper 2004). Previous regeneration studies have focused primarily on seedling establishment and survival as the chief factor in ash population persistence (Kashian and Witter 2011, Klooster et al. 2014). Unlike Klooster et al. (2014), who observed only uncommon sprouting from stumps in forest stands, stump sprouts accounted on average for $32 \%$ of all ash regeneration at our sites (Fig. 2). Similar to their results, however, our survey showed that stump sprouts have lower vigour than saplings originating from seeds $\left(t_{1,138}=-2.55 ; \mathrm{p}=\right.$ 0.0119 ), irrespective of whether the stem is infested by EAB. Stump sprouts could therefore play a role in the survival of ash populations in shrub form, as well as in the succession dynamics following EAB-caused mortality.

Long-term monitoring of ash regeneration and survival are central to understanding post-EAB outbreak dynamics in ash populations, but without a concomitant assessment of infestation levels, they may be insufficient to determine pop- ulation recovery potential. In mature trees, the appearance of external cues lags significantly behind the progress of the infestation. Visual assessments usually underestimate the levels of infestation and do not detect early infestation, therefore they have been deemed unreliable for effective pest management response (Herms and McCullough 2014 but see Flower et al. 2013). However, in the context of monitoring ash regeneration dynamics after an outbreak, the visual assessment method may be appropriate to estimate the prevalence of infestation within the orphaned cohort. In our survey, visual assessment of sapling vigour (on a 1-4 scale) was a significant predictor of EAB infestation status, as confirmed by in situ dissection of stems $(z=2.46 . \mathrm{p}=0.0141)$. Bark cracks and other lesions were also closely associated with EAB infestation $(z=4.74 ; \mathrm{p}<0.0001)$. Exit-holes occurred too rarely to allow statistical tests $(n=7)$, but EAB infestation was confirmed in every sapling where they were observed. Combined, external signs of infestation accurately predicted infestation status $85 \%$ of the time.

\section{Conclusion}

Overall, ash regeneration on impacted sites was abundant but seemed compromised by the persistence of an active EAB population more than ten years after the detection of the outbreak. Plentiful regeneration, including a large proportion of stump sprouts, may allow survival of these species in the landscape for decades, at least in juvenile, low-shrub forms, but it is likely that the key functional role played by ash species will be altered as a result of persistent EAB-caused mortality in maturing trees. Although we may witness an initial shift in the functional role of ash, such as provision of standing dead wood for saproxylic insects and their predators (woodpeckers), they are unlikely to remain an important part of the landscape much past this point.

The fate of ash in our landscape depends on complex interactions between regeneration, EAB population dynamics and the environment. From a management perspective, the protection of a few large trees in the landscape by effective insecticide treatment (e.g., McKenzie et al. 2010) may be a sound strategy, even before we fully understand the trophic interactions at work. Given the good colonisation potential of ash, the preservation of a minimal number of trees could ensure the continued presence of a viable seed cohort, at least in the medium term. Such actions should be based on a sound knowledge of ash autecology, for instance, protecting both male and female trees for dioecious species, and in environments conducive to their regeneration.

Although based on a limited number of sites, this study aimed to provide much-needed information on the potential for ash regeneration in the southern Ontario agricultural landscape. By documenting ash dynamics in the few forested patches that remain near the epicenter of the outbreak, we aimed to: (1) inform managers preoccupied by the future of ash-dominated stands and evaluate tools to assess ash regeneration capacity under residual EAB populations; and, (2) provide context for future studies, including a formal comparisons of ash regeneration between populations and under a range of environmental conditions. Another important question which remains open is the survival of EAB larvae in regenerating stems until their emergence at the adult stage. These studies are critical to obtain a clear picture of the trophic relationships between $\mathrm{EAB}$ and ash regeneration. 


\section{Acknowledgements}

We wish to thank Craig Zimmerman, Hugh Evans and Eric Cleland for their field work, Jean-Lionel Payeur-Poirier, Kevin Good and Hedi Kebli for data management and analysis as well as Sandrine Gautier-Éthier and Kim Bannon for a survey of the literature. Canadian Forest Service (Natural Resources Canada), Ontario Ministry of Natural Resources and Forestry, SERG International members (Ontario and U.S. Forest Service) and the Invasive Species Centre Partnership Fund provided support for this research.

\section{References}

Anulewicz, A., D.G. McCullough and D. Cappaert. 2007. Emerald ash borer (Agrilus planipennis) density and canopy dieback in three North American ash species. Arboriculture \& Urban Forestry. 33(5): 338-349.

Bates, D., M. Maechler, B. Bolker and S. Walker. 2014. Linear mixed-effects models using Eigen and S4 (version 1.1-7). Available from www.R-project.org. Accessed in 2014.

Burns, R.M. and B.H. Honkala. 1990. Silvics of North America: 1. Conifers; 2. Hardwoods. Agriculture Handbook \#654. U.S. U.S Department of Agriculture F.S. 877 p., Washington, DC.

Burr, S.J. and D.G. McCullough. 2014. Condition of green ash (Fraxinus pennsylvanica) overstory and regeneration at three stages of the emerald ash borer invasion wave. C. J. For. Res. 44: 768-76. DOI: $10.1139 /$ cjfr-2013-0415.

Canada Centre for Mapping and Earth Observation. 2010. Land Cover, Circa 2000-Vector (LCC2000-V) (online). Government of Canada, Natural Resources Canada, Earth Sciences Sector. Available from http://geogratis.gc.ca/api/en/nrcan-rncan/ess-sst/0b150cdab1c8-4290-84a2-ef4940d032e3.html. Accessed in 2014.

Cappaert, D., D.G. McCullough, T.M. Poland and N.W. Siegert. 2005. Emerald ash borer in North America: a research and regulatory challenge. Am. Entomol. 51(3): 152-165.

D'Orangeville, L., A. Bouchard and A. Cogliastro. 2008. Post-agricultural forests: Landscape patterns add to stand-scale factors in causing insufficient hardwood regeneration. For. Ecol. Manage. 255 (5-6): 1637-1646. DOI: doi:10.1016/j.foreco.2007.11.023.

Dietze, M.C. and J.S. Clark. 2008. Changing the gap dynamics paradigm: Vegetative regeneration control on forest response to disturbance. Ecol. Mono. 78(3): 331-347. DOI: 10.1890/07-0271.1.

Ellison, A.M., et al. 2005. Loss of foundation species: consequences for the structure and dynamics of forested ecosystems. Front. Ecol. Environ. 3(9): 479-486. DOI: 10.1890/1540-9295(2005)003[0479: Lofscf]2.0.Co;2.

Farrar, J.L. 1995. Trees in Canada. 502 p. Fitzhenry and Whiteside Ltd., Markham, Ontario.

Flower, C.E, K.S. Knight and M.A. Gonzalez-Meler. 2013. Impacts of emerald ash borer induced ash mortality on forest carbon cycling and successional dynamics in the eastern United States. Biological Invasions 15:931-944. DOI 10.1007/s10530-012-0341-7

Gandhi, K.K. and D.A. Herms. 2010. Direct and indirect effects of alien insect herbivores on ecological processes and interactions in forests of eastern North America. Biol. Invasions. 12(2): 389-405. DOI: $10.1007 /$ s10530-009-9627-9.

Haack, R., E. Jendek, H. Liu, K.R. Marchant, T.R. Petrice, T.M. Poland and H. Ye. 2002. The emerald ash borer: A new exotic pest in North America. Michigan Entomological Society Newsletter. 47(3-4): 1-5.

Herms, D.A. and D.G. McCullough. 2014. Emerald ash borer invasion of North America: History, biology, ecology, impacts, and management. Annu. Rev. Entomol. 59(1): 13-30. DOI: doi:10.1146/ annurev-ento-011613-162051.

Jansen, P. and L. Kuiper. 2004. Double green energy from traditional coppice stands in the Netherlands. Biomass Bioenerg. 26(4): 401-402. DOI: doi:10.1016/j.biombioe.2003.08.004.
Jendek, E. 1994. Studies in the East Palaearctic species of the genus Agrilus Dahl, 1923 (Coleoptera: Buprestidaw) Part 1. Entomological Problems. 25(1): 9-25.

Kashian, D.M. and J.A. Witter. 2011. Assessing the potential for ash canopy tree replacement via current regeneration following emerald ash borer-caused mortality on southeastern Michigan landscapes. Forest Ecol. Manag. 261(3): 480-488. DOI: doi:10.1016/j.foreco. 2010.10 .033 .

Klooster, W., D. Herms, K. Knight, C. Herms, D. McCullough, A. Smith, K.K. Gandhi and J. Cardina. 2014. Ash (Fraxinus spp.) mortality, regeneration, and seed bank dynamics in mixed hardwood forests following invasion by emerald ash borer (Agrilus planipennis). Biol. Invasions. 16 (4): 859-873. DOI: 10.1007/s10530-0130543-7.

Knight, K., J. Brown and R. Long. 2013. Factors affecting the survival of ash (Fraxinus spp.) trees infested by emerald ash borer (Agrilus planipennis). Biol. Invasions. 15(2): 371-383. DOI: 10.1007/s10530-012-0292-z.

Knight, K.S., D.A. Herms, J. Cardina, R. Long, K.J.K. Gandhi and C. Herms. 2011. Emerald ash borer aftermath forests: the future of ash ecosystems. In: McManus, Katherine A; Gottschalk, Kurt W., (eds.) 2010. Proceedings. 21st U.S. Department of Agriculture interagency research forum on invasive species 2010. U.S. Department of Agriculture, Forest Service, Northern Research Station. 97 p.

Knight, K.S., J.M. Slavicek, R. Kappler, E. Pisarczyk, E. Wiggin and K. Menard. 2012. Dynamics of surviving ash (Fraxinus spp.) populations in areas long infested by emerald ash borer (Agrilus planipennis). Proc. 4th Int. Workshop Genetics Host-Parasite Interact. pp. 143-152.

Kominoski, J.S., C.M. Pringle, B.A. Ball, M.A. Bradford, D.C. Coleman, D.B. Hall and M.D. Hunter. 2007. Nonadditive effects of leaf litter species diversity on breakdown dynamics in a detritusbased stream. Ecol. 88(5): 1167-1176. DOI: 10.1890/06-0674.

Little, E.L., Jr. 1971. Atlas of United States trees, volume 1, conifers and important hardwoods: U.S (online). Available from http://esp.cr.usgs.gov/data/little/. Accessed in 2015.

MacFarlane, D.W. and S.P. Meyer. 2005. Characteristics and distribution of potential ash tree hosts for emerald ash borer. Forest Ecol. Manage. 213(1-3): 15-24. DOI: 10.1016/j.foreco.2005.03.013.

McKenzie, N., B. Helson, D. Thompson, G. Otis, J. McFarlane, T. Buscarini and J. Meating. 2010. Azadirachtin: an effective systemic insecticide for control of Agrilus planipennis (Coleoptera: Buprestidae). Forest Entomol. 103(3): 708-717. DOI: 10.1603/ec09305.

OMNRF (Ontario Ministry of Natural Resources and Forestry). 2015. Forest Insect Damage Event data, Land Information Ontario (online). Available from https://www.javacoeapp.lrc.gov.on.ca/ geonetwork. Accessed in 2015.

Poland, T.M. and D.G. McCullough. 2006. Emerald ash borer: invasion of the urban forest and the threat to North America's ash resource. J. For. 104(3): 118-124.

Ryall, K.L., J.G. Fidgen and J.J. Turgeon. 2011. Detectability of the emerald ash borer (Coleoptera: Buprestidae) in asymptomatic urban trees by using branch samples. Environ. Entomol. 40(3): 679-688. DOI: $10.1603 /$ en 10310

Siegert, N.W., D.G. McCullough, D.W. Williams, I. Fraser, T.M. Poland and S.J. Pierce. 2010. Dispersal of Agrilus planipennis (Coleoptera: Buprestidae) from discrete epicenters in two outlier sites. Environ. Entomol. 39(2): 253-265.

Spooner, B. and P. Roberts. 2010. Fungi. Collins New Naturalist Library, Book 96. Harper Collins, UK. 608 p.

Statistical Package R. 2009. R: A language and environment for statistical computing (online). Available from http://www.Rproject.org. Accessed in 2014.

Tanis, S.R. and D.G. McCullough. 2012. Differential persistence of blue ash and white ash following emerald ash borer invasion. C. J.For. Res. 42(8): 1542-1550. DOI: 10.1139/x2012-103. 
Timms, L.L., S.M. Smith and P. De Groot. 2006. Patterns in the within-tree distribution of the emerald ash borer Agrilus planipennis (Fairmaire) in young, green-ash plantations of south-western Ontario, Canada. Agri. Forest Entomol. 8(4): 313-321. DOI: 10.1111/j.1461-9563.2006.00311.x.

USDA and M.S.U. 2004. Emerald ash borer (online). Available at: http://www.emeraldashborer.info/index.cfm\#sthash.gDF6w5pb.dpbs. Accessed in 2015.

USDA and NRCS. 2009. The PLANTS Database (online). Available http://plants.usda.gov/. Accessed in 2014.

USDA. 2010. Fire Effects Information System (online). Available at: http://www.fs.fed.us/database/feis/plants/index.html. Accessed in 2014.
Venables, W.N. and B.D. Ripley. 2002. Modern applied statistics with S. 481 p. Springer Science \& Business Media, New-York.

Wei, X., D. Reardon, Y. Wu and J.H. Sun. 2004. Emerald ash borer, Agrilus planipennis (Coleoptera: Buprestidae), in China: a review and distribution survey. Acta Entomol. Sinica. 47(5): 679-685.

Wright, J.W. 1959. Silvical characteristics of white ash (Fraxinus americana). Station Paper NE-123. Upper Darby, PA U.S. Department of Agriculture, Forest Service, Northeastern Forest Experiment Station. 19 p.

\section{Supplementary material}

Site-level description of habitat, matrix type, and companion overstory species. Relative abundance of ash is based on basal area.

\begin{tabular}{|c|c|c|c|c|c|}
\hline Region & Site & Habitat & Matrix & $\%$ Ash & Major overstory species \\
\hline \multirow[t]{6}{*}{ Impacted } & 1 & Woodlot & Urban & 73.4 & White oak, hawthorn \\
\hline & 2 & Woodlot & Agricultural & 39.5 & Elm \\
\hline & 3 & Riparian & Agricultural & 82.6 & Elm, silver maple \\
\hline & 4 & Riparian & Agricultural & 68.5 & Elm, silver maple \\
\hline & 5 & Riparian & Agricultural & 72.2 & Hawthorn \\
\hline & 6 & Riparian & Agricultural & 85.3 & Elm \\
\hline \multirow[t]{24}{*}{ Reference } & 7 & Riparian & Urban & 97.6 & - \\
\hline & 8 & Riparian & Urban & 72.0 & Sugar maple, basswood \\
\hline & 9 & Riparian & Urban & 98.8 & - \\
\hline & 10 & Riparian & Urban & 52.0 & Elm, eastern white pine, sugar maple, ironwood \\
\hline & 11 & Riparian & Urban & 83.2 & Willow, walnut \\
\hline & 12 & Riparian & Urban & 90.8 & - \\
\hline & 13 & Riparian & Agricultural & 74.1 & Sugar maple, eastern white pine, red oak, walnut \\
\hline & 14 & Riparian & Agricultural & 55.3 & Bitternut hickory, elm, ironwood \\
\hline & 15 & Riparian & Agricultural & 84.3 & Black maple, elm \\
\hline & 16 & RIparian & Agricultural & 60.0 & Bitternut hickory, walnut, elm, black maple \\
\hline & 17 & Riparian & Agricultural & 65.9 & Black maple, basswood, elm \\
\hline & 18 & Riparian & Agricultural & 39.0 & Walnut, elm, basswood, black maple \\
\hline & 19 & Woodlot & Urban & 91.0 & Elm \\
\hline & 20 & Woodlot & Urban & 68.3 & Shagbark hickory, red oak \\
\hline & 21 & Woodlot & Urban & 68.6 & Bur oak, shagbark hickory \\
\hline & 22 & Woodlot & Urban & 90.2 & Buckthorn \\
\hline & 23 & Woodlot & Urban & 86.4 & Bur oak \\
\hline & 24 & Woodlot & Urban & 80.4 & Red oak \\
\hline & 25 & Woodlot & Agricultural & 46.4 & Red maple, silver maple, elm \\
\hline & 26 & Woodlot & Agricultural & 75.1 & Red maple, elm, tulip tree \\
\hline & 27 & Woodlot & Agricultural & 53.9 & Silver maple, white oak, cottonwood, red maple, elm \\
\hline & 28 & Woodlot & Agricultural & 56.2 & Cottonwood, silver maple, basswood, white oak \\
\hline & 29 & Woodlot & Agricultural & 78.0 & Red maple \\
\hline & 30 & Woodlot & Agricultural & 55.3 & Red oak, red maple, beech, black cherry \\
\hline
\end{tabular}

